\title{
Kinetic and Mechanism of the Addition of Benzylamines to $\alpha$-Phenyl- $\beta$-thiophenylacrylonitriles in Acetonitrile
}

\author{
Jaeyoung Hwang, ${ }^{a}$ Kiyull Yang, ${ }^{b}$ In Sun Koo,,${ }^{b,}$ Dae Dong Sung, ${ }^{c}$ and Ikchoon Lee ${ }^{d}$ \\ ${ }^{a}$ Department of Chemistry, Gyeongsang National University, Jinju 660-701, Korea \\ ${ }^{\mathrm{b}}$ Department of Chemistry Education and the Research Institute of Natural Science, Gyeongsang National University, \\ Jinju 660-701, Korea. E-mail: iskoo@gsnu.ac.kr \\ ${ }^{\mathrm{c}}$ Department of Chemistry, Dong-A University, Busan 604-714, Korea \\ ${ }^{\mathrm{d}}$ Department of Chemistry, Inha University, Incheon 402-751, Korea \\ Received March 8, 2006
}

\begin{abstract}
Nucleophilic addition reactions of $p$-substitutedbenzylamines $\left(\mathrm{XC}_{6} \mathrm{H}_{4} \mathrm{CH}_{2} \mathrm{NH}_{2}\right)$ to $\alpha$-phenyl- $\beta$-thiophenylacrylonitriles $\left(\mathrm{YC}_{4} \mathrm{SH}_{2} \mathrm{CH}=\mathrm{C}(\mathrm{CN}) \mathrm{C}_{6} \mathrm{H}_{4} \mathrm{Y}^{\prime}\right)$ have been studied in acetonitrile at 25.0, 30.0, and 35.0 ${ }^{\circ} \mathrm{C}$. The reactions take place in single step in which the $\mathrm{C}_{\beta}$-N bond formation and proton transfer to $\mathrm{C}_{\alpha}$ of $\alpha$-phenyl- $\beta$ thiophenylacrylonitriles occur concurrently with four-membered cyclic transition structure. These mechanistic conclusions are drawn based on (i) the large negative $\rho_{\mathrm{X}}$ and large positive $\rho_{\mathrm{Y}^{\prime}}$ values and also large magnitude of $\rho_{\mathrm{X}}$, (ii) the negative sign and large magnitude of the cross-interaction constants $\left(\rho_{\mathrm{XY}}\right)$, (iii) the normal kinetic isotope effects $\left(k_{\mathrm{H}} / k_{\mathrm{D}}>1.0\right)$, and (iv) relatively low $\Delta \mathrm{H}^{\neq}$and large negative $\Delta \mathrm{S}^{\neq}$values.
\end{abstract}

Key Words : Nucleophilic addition reaction, Cross-interaction constant, Kinetic isotope effects, Four-center cyclic transition state

\section{Introduction}

In nucleophilic additions of amines $\left(\mathrm{XRNH}_{2}\right)$ to activated alkenes $\left(\mathrm{YC}_{6} \mathrm{H}_{4} \mathrm{CH}=\mathrm{CZZ}\right)$, development of resonance and solvation of the incipient carbanion in the TS often lag behind $\mathrm{C}-\mathrm{N}$ bond formation, ${ }^{1}$ an exaggerated form of this can be given as $\mathbf{1}$ in eq. (1). In aqueous solution,

$\mathrm{YC}_{6} \mathrm{H}_{4} \mathrm{CH}=\mathrm{CZZ}+\mathrm{XRNH}_{2} \rightleftharpoons\left[\begin{array}{c}\mathrm{YC}_{6} \mathrm{H}_{4} \mathrm{CH} \\ \vdots \\ \mathrm{XRNH}_{2} \\ 1\end{array}\right]^{1}$

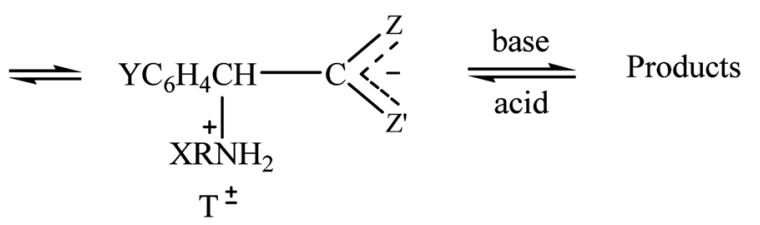

The reaction proceeds through a zwitterionic intermediate, ${ }^{1} \mathrm{~T}^{ \pm}$, (eq. 1) whereas in acetonitrile the adduct was found to form in a single step, ${ }^{2}$. The transition state (TS) imbalance, $\mathbf{1}$, is far more pronounced for the reaction in

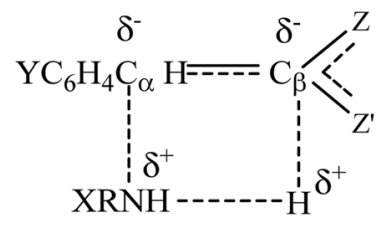

aqueous solution than in acetonirile. Due to weak solvation by acetonitrile to stabilize the carbanion $\mathrm{T}^{ \pm}$and hydrogen bonding by $\mathrm{N}-\mathrm{H}$ proton to negative charge localized on $\mathrm{C}_{\beta}$ in the TS(2), the imbalance in the amine additions in acetonirile becomes very weak. Nevertheless,

The partially localized incipient anionic charge on $\mathrm{C}_{\beta}(\mathbf{1})$ due to the imbalance was found to manifest itself in the strength of hydrogen bonding in the TS (2); thus a relatively strong imbalance has led to a stronger kinetic isotope effect $\left(k_{\mathrm{H}} / k_{\mathrm{D}}>1.0\right)$ involving deuterated amines $\left(\mathrm{XRND}_{2}\right){ }^{3} \mathrm{An}-$ other interesting observation is that the sign and magnitude $\left(\rho_{\mathrm{XY}}=-0.6\right.$ to -0.8$)$ of the cross-interaction constant, ${ }^{3,4} \rho_{\mathrm{XY}}$ in eqs. 2 where $X$ and $Y$ are substituents in the nucleophile and substrate, respectively, are in general agreement with those for bond formation in the concerted bimolecular nucleophilic substitution $\left(\mathrm{S}_{N} 2\right)$ reactions. ${ }^{2,4(a)}$

$$
\begin{gathered}
\log \left(k_{\mathrm{XY}} / k_{\mathrm{HH}}\right)=\rho_{\mathrm{X}} \sigma_{\mathrm{X}}+\rho_{\mathrm{Y}} \sigma_{\mathrm{Y}}+\rho_{\mathrm{XY}} \sigma_{\mathrm{X}} \sigma_{\mathrm{Y}} \\
\rho_{\mathrm{XY}}=\partial \rho_{\mathrm{Y}} / \partial \sigma_{\mathrm{X}}=\partial \rho_{\mathrm{X}} / \partial \sigma_{\mathrm{Y}}
\end{gathered}
$$

In this work, we carried out kinetic studies of the benzylamine (BA, $\mathrm{XC}_{6} \mathrm{H}_{4} \mathrm{CH}_{2} \mathrm{NH}_{2}$ ) addition in acetonitrile at 25.0, 30.0, and $35.0{ }^{\circ} \mathrm{C}$ to $\alpha$-phenyl- $\beta$-thiophenyl acrylonitriles (PTA: $\left.\mathrm{YC}_{4} \mathrm{SH}_{2} \mathrm{CH}=\mathrm{C}(\mathrm{CN}) \mathrm{C}_{6} \mathrm{H}_{4} \mathrm{Y}^{\prime}\right)$ where substituents $\mathrm{Y}$ and $\mathrm{Y}^{\prime}$ in phenyl ring and thiophene ring are varied respectively (eq. 3). In this paper we report the nature and substituents effect of the thiophene ring with a sulfur atom for the BA addition reaction to PTA. We try to demonstrate that there is TS imbalance in the one step amine addition to olefins in acetonitrile, by determining various selectivity parameters $\left(\rho_{\mathrm{Y}}, \rho_{\mathrm{Y}^{\prime}}, \rho_{\mathrm{XY}}\right.$ and $\left.\beta_{\mathrm{X}}\right)$ and the kinetic isotope effects, $k_{\mathrm{H}} / k_{\mathrm{D}}$. 
<smiles>[Y]c1ccc(CN)cc1</smiles><smiles>[Y]c1ccc(CNC(C#N)c2ccc([Y])s2)cc1</smiles>

\section{Results and Discussion}

The kinetic law obeyed in the present reactions is given by eq. (4). No catalysis by a second benzylamine molecule was detected. Plots of pseudo-first-order rate constant, $k_{\mathrm{obs}}$ against [BA] were linear as shown Figure 1, and the secondorder rate constants, $k_{2}$, determined from the slopes of these plots are summarized in Table 1.

$$
\text { rate }=k_{2}[\mathrm{BA}][\mathrm{PTA}]=k_{\mathrm{obs}}[\mathrm{PTA}]
$$

The selectivity parameters, Hammett coefficients $\rho_{\mathrm{X}}, \rho_{\mathrm{Y}}$ and $\rho_{Y^{\prime}}$ values and Brønsted $\beta_{\mathrm{X}}$ values, are also shown in Table 1 together with the cross-interaction constant $\rho_{\mathrm{XY}}$ (eqs. 2 ). The $\rho_{\mathrm{Y}}$ values were determined by the plots $\log k_{2}$ versus normal $\sigma_{p}$ substituents constant. The 5,2-substituted thiophene system is considered formally analogous to parasubstituted benzene derivatives; such set have generally been correlated with $\sigma_{p}$ constants depending on the nature of reaction site. ${ }^{5}$ Ionization constants of 5-substituted thiophene-2-carboxylic acid in pure water at $25.0^{\circ} \mathrm{C}$ give very good correlation with $\sigma_{p}$ constants $(\rho=1.10, n=5, r=$

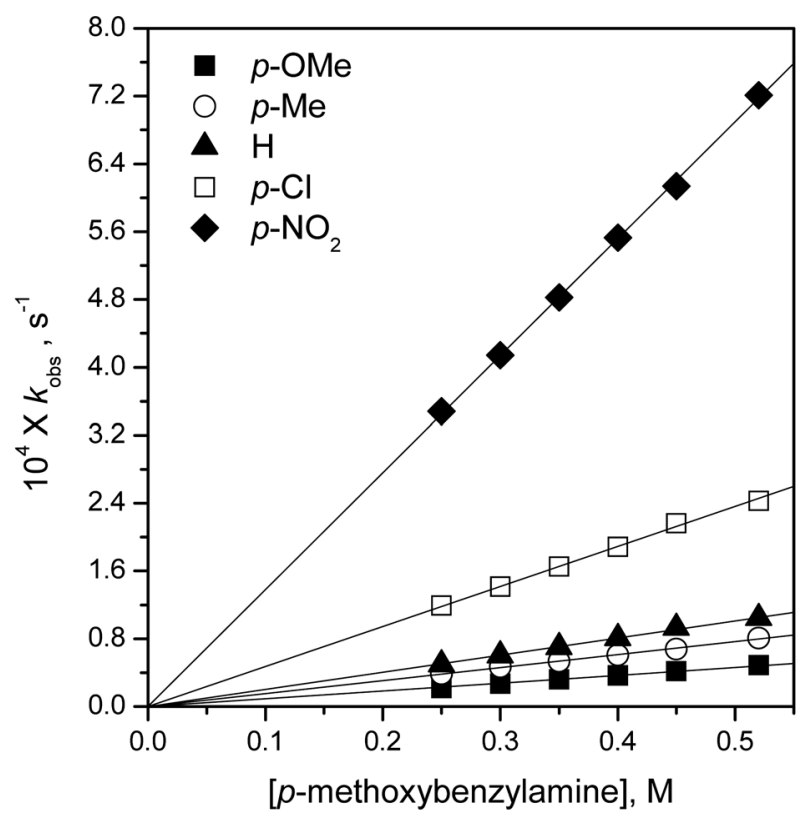

Figure 1. Plots of $k_{\text {obs }} v s$. [ $p$-methoxybenzylamine] for the addition reactions of $\mathrm{MeC}_{4} \mathrm{SH}_{2} \mathrm{CH}=\mathrm{C}(\mathrm{CN}) \mathrm{C}_{6} \mathrm{H}_{4} \mathrm{Y}^{\prime}$ at $25.0^{\circ} \mathrm{C}$.
Table 1. Second-order rate constants, $10^{4} k_{2}, \mathrm{M}^{-1} \mathrm{~s}^{-1}$ for addition reactions of $\alpha$-phenyl- $\beta$-thiophenylacylonitriles with X-substituted benzylamines in acetonitrile at $25.0{ }^{\circ} \mathrm{C}$

\begin{tabular}{ccccccc}
\hline \multirow{2}{*}{$\mathrm{Y}$} & $\mathrm{Y}^{\prime}$ & \multicolumn{5}{c}{$\mathrm{X}$} \\
\cline { 3 - 7 } & & $p$-OMe & $p-\mathrm{Me}$ & $\mathrm{H}$ & $p$-Cl & $p-\mathrm{NO}_{2}$ \\
\hline & $p-\mathrm{OMe}$ & 0.922 & 0.891 & 0.670 & 0.572 & 0.370 \\
& $p-\mathrm{Me}$ & 1.53 & 1.24 & 0.993 & 0.754 & 0.441 \\
$\mathrm{Me}$ & $\mathrm{H}$ & 2.02 & 1.65 & 1.21 & 0.882 & 0.483 \\
& $p-\mathrm{Cl}$ & 4.72 & 3.75 & 2.62 & 1.62 & 0.584 \\
& $p-\mathrm{NO}_{2}$ & 13.8 & 7.44 & 5.05 & 2.79 & 0.751 \\
\hline & $p-\mathrm{OMe}$ & 1.74 & 1.45 & 1.12 & 0.881 & 0.532 \\
& $p-\mathrm{Me}$ & 2.67 & 2.02 & 1.51 & 1.09 & 0.571 \\
$\mathrm{H}$ & $\mathrm{H}$ & 5.29 & 4.08 & 2.70 & 1.56 & 0.704 \\
& $p-\mathrm{Cl}$ & 8.91 & 5.95 & 3.88 & 2.39 & 0.802 \\
& $p-\mathrm{NO}{ }_{2}$ & 36.0 & 18.4 & 11.4 & 5.93 & 1.10 \\
\hline & $p-\mathrm{OMe}$ & 4.19 & 3.48 & 2.53 & 1.71 & 0.682 \\
& $p-\mathrm{Me}$ & 5.68 & 4.67 & 3.13 & 1.98 & 0.784 \\
$\mathrm{Br}$ & $\mathrm{H}$ & 11.8 & 8.97 & 6.02 & 3.74 & 1.18 \\
& $p-\mathrm{Cl}$ & 18.9 & 13.2 & 8.47 & 4.67 & 1.30 \\
& $p-\mathrm{NO}_{2}$ & 139 & 83.9 & 46.9 & 20.9 & 2.29 \\
\hline
\end{tabular}

0.988). ${ }^{5(\mathrm{c})}$ Both the Hammett (for $\mathrm{Y}$ and $\mathrm{Y}^{\prime}$ ) and Brønsted plots are very good linear as shown in Figures 2, 3 and 4. The $\beta_{\mathrm{X}}\left(\beta_{\text {nuc }}\right)$ values were determined by the plots of $\log k_{2}$ $(\mathrm{MeCN})$ versus $\mathrm{p} K_{\mathrm{a}}\left(\mathrm{H}_{2} \mathrm{O}\right)$ of benzylamines. This procedure was found to be reliable ${ }^{6}$ since the $\mathrm{p} K_{\mathrm{a}}(\mathrm{MeCN})$ varies in parallel with the $\mathrm{p} K_{\mathrm{a}}\left(\mathrm{H}_{2} \mathrm{O}\right)$ with a reasonably constant difference of $\Delta K_{\alpha}\left(=\mathrm{p} K_{\mathrm{a}}(\mathrm{MeCN})-\mathrm{p} K_{\mathrm{a}}\left(\mathrm{H}_{2} \mathrm{O}\right)\right)=7.5$.

As shown in Table 1 , the second-order rate constant $\left(k_{2}\right)$ increases as the substituents $\mathrm{Y}^{\prime}$ and $\mathrm{Y}$ in the phenyl and thiophene moiety changes from an electron-donating group to an electron-withdrawing group, and increases as the

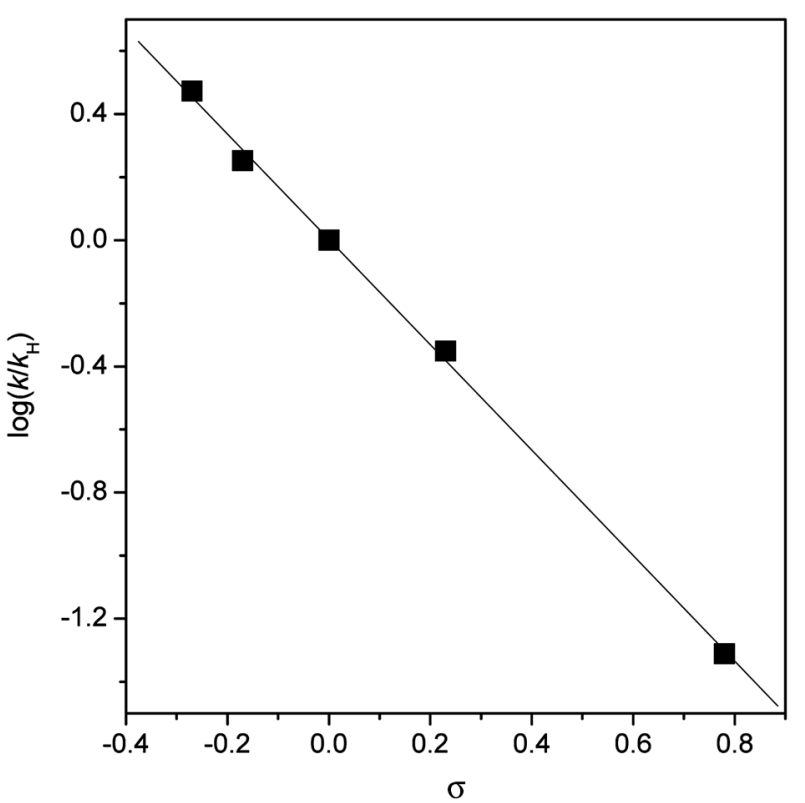

Figure 2. The typical Hammett plot of $\mathrm{NH}_{2} \mathrm{CH}_{2} \mathrm{C}_{6} \mathrm{H}_{4} \mathrm{X}$ for the addition reactions of $\mathrm{C}_{4} \mathrm{SH}_{3} \mathrm{CH}=\mathrm{C}(\mathrm{CN}) \mathrm{C}_{6} \mathrm{H}_{4} \mathrm{NO}_{2}$ at $25.0{ }^{\circ} \mathrm{C}$. 


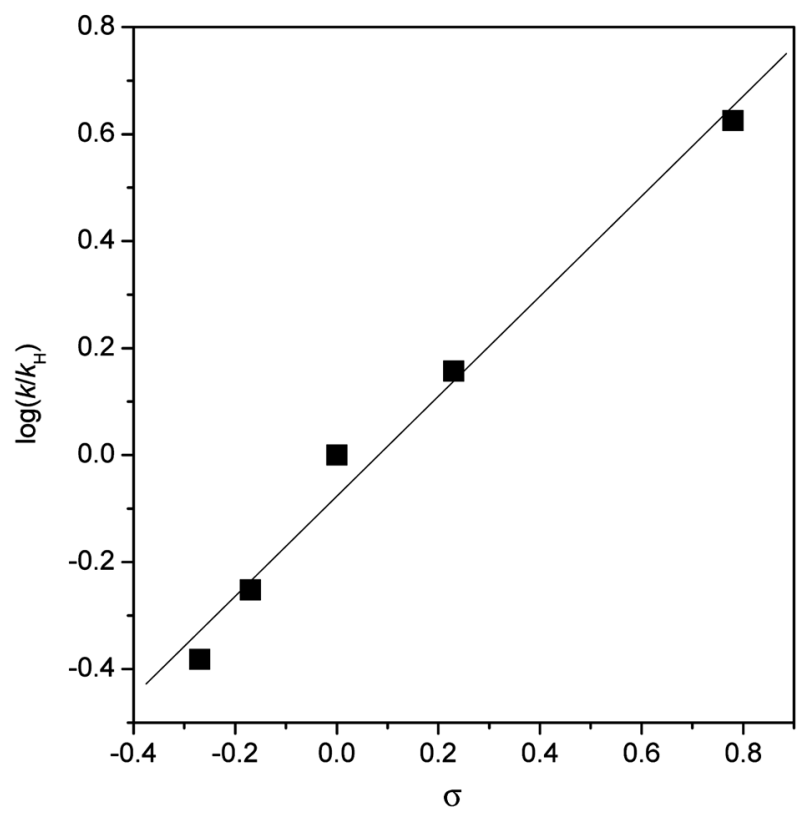

Figure 3. The typical Hammett plot of $\mathrm{NH}_{2} \mathrm{CH}_{2} \mathrm{C}_{6} \mathrm{H}_{5}$ for the addition reactions of $\mathrm{C}_{4} \mathrm{SH}_{3} \mathrm{CH}=\mathrm{C}(\mathrm{CN}) \mathrm{C}_{6} \mathrm{H}_{4} \mathrm{Y}^{\prime}$ at $25.0{ }^{\circ} \mathrm{C}$.

substituent $\mathrm{X}$ in the benzylamine changes from an electronwithdrawing group to an electron-donating group for the addition reaction of PTA with benzylamines. This result indicates that the rates are faster for a stronger nucleophile

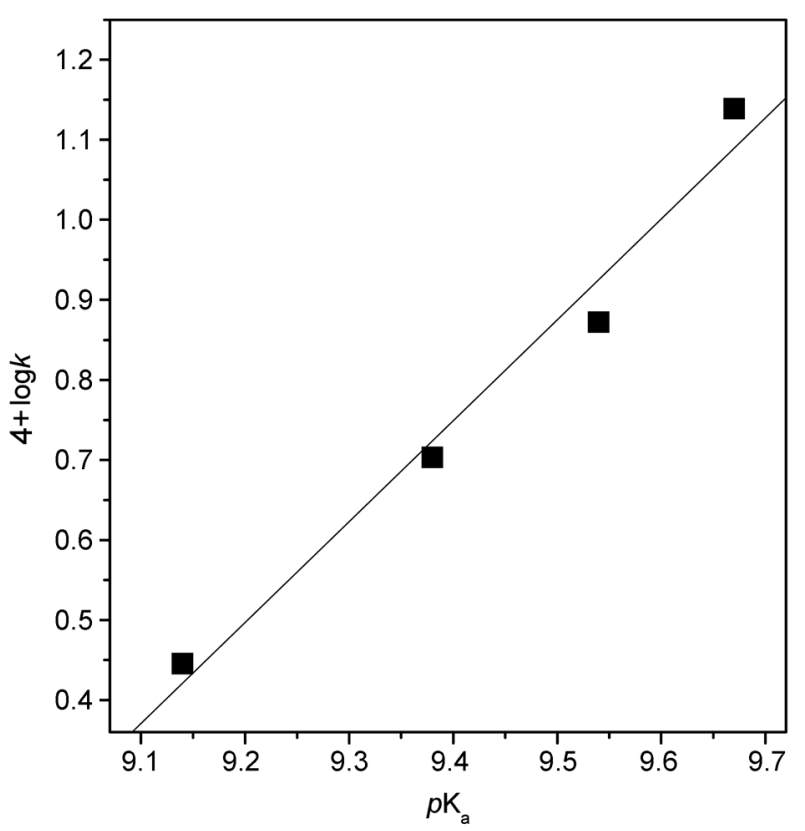

Figure 4. The typical Brønsted plot of $\mathrm{NH}_{2} \mathrm{CH}_{2} \mathrm{C}_{6} \mathrm{H}_{4} \mathrm{X}$ for the addition reactions of $\mathrm{MeC}_{4} \mathrm{SH}_{2} \mathrm{CH}=\mathrm{C}(\mathrm{CN}) \mathrm{C}_{6} \mathrm{H}_{4} \mathrm{NO}_{2}$ at $25.0{ }^{\circ} \mathrm{C}$.

$\left(\delta \sigma_{\mathrm{X}}<0\right)$ and for the substrate (PTA) with a stronger electron-withdrawing group in phenyl ring $\left(\delta \sigma_{\mathrm{Y}^{\prime}}>0\right)$ and thiophene ring $\left(\delta \sigma_{\mathrm{Y}}>0\right)$ as exhibit in a typical nucleophilic addition reaction. The $\rho_{Y^{\prime}}$ value in the present system is

Table 2. Hammett $\left(\rho_{\mathrm{X}}, \rho_{\mathrm{Y}^{\prime}}\right.$ and $\left.\rho_{\mathrm{Y}}\right)$ and Brønsted $\left(\beta_{\mathrm{X}}\right)$ coefficients for the reactions of $\alpha$-phenyl- $\beta$-thiophenylacrylonitriles with Xsubstituted benzylamines in acetonitrile at $25.0{ }^{\circ} \mathrm{C}$

(i) $\rho_{\mathrm{X}}$ and $\left(\beta_{\mathrm{X}}\right)$ values $^{a}$

\begin{tabular}{cccccc}
\hline $\mathrm{Y} / \mathrm{Y}^{\prime}$ & $p$-OMe & $p$-Me & $\mathrm{H}$ & $p-\mathrm{Cl}$ & $p-\mathrm{NO}_{2}$ \\
\hline $\mathrm{Me}$ & $-0.38 \pm 0.02$ & $-0.50 \pm 0.09$ & $-0.58 \pm 0.05$ & $-0.86 \pm 0.05$ & $-1.14 \pm 0.03$ \\
$\mathrm{Me}$ & $(0.43 \pm 0.06)$ & $(0.58 \pm 0.08)$ & $(0.69 \pm 0.03)$ & $(0.89 \pm 0.09)$ & $(1.26 \pm 0.03)$ \\
$\mathrm{H}$ & $-0.48 \pm 0.09$ & $-0.50 \pm 0.03$ & $-0.83 \pm 0.04$ & $-0.96 \pm 0.05$ & $-1.37 \pm 0.07$ \\
$\mathrm{H}$ & $(0.56 \pm 0.04)$ & $(0.73 \pm 0.07)$ & $(1.01 \pm 0.09)$ & $(1.07 \pm 0.03)$ & $(1.43 \pm 0.04)$ \\
$\mathrm{Br}$ & $-0.75 \pm 0.09$ & $-0.85 \pm 0.03$ & $-0.94 \pm 0.01$ & $-1.09 \pm 0.03$ & $-1.67 \pm 0.09$ \\
$\mathrm{Br}$ & $(0.75 \pm 0.08)$ & $(0.89 \pm 0.07)$ & $(0.95 \pm 0.07)$ & $(1.15 \pm 0.03)$ & $(1.55 \pm 0.01)$ \\
\hline
\end{tabular}

${ }^{a}$ The correlation coefficients were better than 0.992 in all cases.

(ii) $\rho_{Y^{\prime}}$ values $^{b}$

\begin{tabular}{ccrrrr}
\hline $\mathrm{Y} / \mathrm{X}$ & $p$-OMe & \multicolumn{1}{c}{$p$-Me } & \multicolumn{1}{c}{$\mathrm{H}$} & \multicolumn{1}{c}{$p$-Cl } & $p$ - $\mathrm{NO}_{2}$ \\
\hline $\mathrm{Me}$ & $1.09 \pm 0.06$ & $0.881 \pm 0.03$ & $0.822 \pm 0.05$ & $0.652 \pm 0.06$ & $0.283 \pm 0.08$ \\
$\mathrm{H}$ & $1.24 \pm 0.05$ & $1.02 \pm 0.04$ & $0.941 \pm 0.07$ & $0.781 \pm 0.06$ & $0.301 \pm 0.09$ \\
$\mathrm{Br}$ & $1.43 \pm 0.04$ & $1.30 \pm 0.07$ & $1.20 \pm 0.08$ & $1.03 \pm 0.09$ & $0.494 \pm 0.09$ \\
\hline
\end{tabular}

${ }^{b}$ The correlation coefficients were better than 0.995 in all cases.

(iii) $\rho_{\mathrm{Y}}$ values $^{c}$

\begin{tabular}{cccccc}
\hline $\mathrm{X} / \mathrm{Y}^{\prime}$ & $p-\mathrm{OMe}$ & $p-\mathrm{Me}$ & $\mathrm{H}$ & $p-\mathrm{Cl}$ & $p-\mathrm{NO}_{2}$ \\
\hline$p-\mathrm{OMe}$ & $1.65 \pm 0.09$ & $1.43 \pm 0.03$ & $1.89 \pm 0.08$ & $1.50 \pm 0.09$ & $2.51 \pm 0.02$ \\
$p-\mathrm{Me}$ & $1.49 \pm 0.06$ & $1.45 \pm 0.04$ & $1.82 \pm 0.07$ & $1.37 \pm 0.02$ & $2.64 \pm 0.06$ \\
$\mathrm{H}$ & $1.45 \pm 0.04$ & $1.25 \pm 0.08$ & $1.73 \pm 0.04$ & $1.28 \pm 0.08$ & $2.43 \pm 0.03$ \\
$p-\mathrm{Cl}$ & $1.19 \pm 0.08$ & $1.05 \pm 0.02$ & $1.57 \pm 0.01$ & $1.16 \pm 0.06$ & $2.20 \pm 0.03$ \\
$p-\mathrm{NO}_{2}$ & $0.654 \pm 0.02$ & $0.624 \pm 0.02$ & $0.970 \pm 0.01$ & $0.872 \pm 0.03$ & $1.22 \pm 0.02$ \\
\hline
\end{tabular}

${ }^{c}$ The correlation coefficients were better than 0.992 in all cases. 
much smaller than $\rho_{\mathrm{Y}}$ value. This differs from the result for the addition of benzylamines to $\beta$-cyanostilbenes in acetonitrile. $^{2(\mathrm{e})}$ However, this is not surprising since sulfur atom is in the vicinity of the reaction center in the present system. The higher $\rho_{\mathrm{Y}}$ value is due to the strong electron transmission efficiencies between sulfur atom and reaction center and also short range interaction of 5-membered ring. ${ }^{7}$ The large positive $\rho_{\mathrm{Y}}$ and $\rho_{\mathrm{Y}^{\prime}}$ values and the large negative $\rho_{\mathrm{X}}$ values indicate that the negative charge development at $\mathrm{C}_{\beta}$ in the TS. The large positive $\rho_{\mathrm{Y}}$ and $\rho_{\mathrm{Y}^{\prime}}$ are indication of a strong anionic charge development at the $\mathrm{C}_{\alpha}$ and $\mathrm{C}_{\beta}$ in the $\mathrm{TS}$, and also the anionic charge development at the $\mathrm{C}_{\alpha}$ in the $\mathrm{TS}$ as a result of the lag (1) in the resonance development into the activating group, $\mathrm{Z}=\mathrm{CN}$.

The sign of $\rho_{\mathrm{XY}}$ and $\rho_{\mathrm{XY}}$ shown in Table 2 are negative, as observed in all the bond formation process in nucleophilic substitution and addition reactions. ${ }^{2(\mathrm{e}), 4(\mathrm{a}), 8}$ The large magnitude of $\rho_{\mathrm{XY}}$ and $\rho_{\mathrm{XY}}$ is reflecting a stronger interaction of the substituents in the nucleophile with those in the phenyl and thiophene ring. Another important result is that the sign of $\rho_{\mathrm{YY}}$ is positive. The positive $\rho_{i j}$ is normally obtained between substituents $i$ and $j$ in the bond cleavage process between them. ${ }^{4(\mathrm{a}), 8}$ In the present reaction, as the nucleophile (benzylamine) attacks $\mathrm{C}_{\beta}$, the pi-bond between $\mathrm{C}_{\beta}$ (linked to thiophene ring) and $\mathrm{C}_{\alpha}$ (linked to phenyl ring) is partially broken in the TS so that the sign of $\rho_{\mathrm{YY}}$ becomes positive. The positive $\rho_{\mathrm{Y} Y^{\prime}}$ also indicates that a stronger electron

Table 3. Cross-interaction constant, $\rho_{\mathrm{XY}}, \rho_{\mathrm{XY}}$ and $\rho_{\mathrm{YY}}$ for the reactions of $\alpha$-phenyl- $\beta$-thiophenylacrylonitriles with $\mathrm{X}$-substituted benzylamines in acetonitrile at $25.0{ }^{\circ} \mathrm{C}$

(i) $\rho_{\mathrm{XY}}{ }^{a}$

\begin{tabular}{cc}
\hline $\mathrm{Y}^{\prime}$ & $\rho_{\mathrm{XY}}$ \\
\hline$p-\mathrm{OMe}$ & $-0.94 \pm 0.06$ \\
$p-\mathrm{Me}$ & $-0.91 \pm 0.08$ \\
$\mathrm{H}$ & $-0.88 \pm 0.02$ \\
$p-\mathrm{Cl}$ & $-0.57 \pm 0.06$ \\
$p-\mathrm{NO}_{2}$ & $-0.32 \pm 0.03$ \\
\hline
\end{tabular}

${ }^{a}$ The correlation coefficients were better than 0.993 in all cases.

(ii) $\rho_{\mathrm{XY}}{ }^{b}$

\begin{tabular}{cc}
\hline $\mathrm{Y}$ & $\rho_{\mathrm{XY}}$, \\
\hline $\mathrm{Me}$ & $-0.72 \pm 0.03$ \\
$\mathrm{H}$ & $-0.83 \pm 0.03$ \\
$\mathrm{Br}$ & $-0.87 \pm 0.03$ \\
\hline
\end{tabular}

${ }^{b}$ The correlation coefficients were better than 0.992 in all cases.

(iii) $\rho_{\mathrm{YY}}{ }^{c}$

\begin{tabular}{cc}
\hline $\mathrm{X}$ & $\rho_{\mathrm{YY}^{\prime}}$ \\
\hline$p-\mathrm{OMe}$ & $0.85 \pm 0.08$ \\
$p-\mathrm{Me}$ & $1.06 \pm 0.01$ \\
$\mathrm{H}$ & $0.96 \pm 0.06$ \\
$p-\mathrm{Cl}$ & $0.96 \pm 0.08$ \\
$p-\mathrm{NO}_{2}$ & $0.54 \pm 0.08$ \\
\hline
\end{tabular}

${ }^{c}$ The correlation coefficients were better than 0.995 in all cases.
Table 4. Kinetic isotope effects on the second order rate constants, $10^{4} k_{2}, \mathrm{M}^{-1} \mathrm{~s}^{-1}$ for the addition reactions $\alpha$-phenyl- $\beta$-thiophenylacrylonitriles with deuterated $\mathrm{X}$ - substituted benzylamines in acetonitrile at $25.0^{\circ} \mathrm{C}$

\begin{tabular}{cccccc}
\hline $\mathrm{X}$ & $\mathrm{Y}$ & $\mathrm{Y}^{\prime}$ & $k_{\mathrm{H}}$ & $k_{\mathrm{D}}$ & $k_{\mathrm{H}} / k_{\mathrm{D}}$ \\
\hline$p-\mathrm{OMe}$ & $\mathrm{Me}$ & $p-\mathrm{NO}_{2}$ & 13.8 & 5.76 & 2.40 \\
$p-\mathrm{NO}_{2}$ & $\mathrm{Me}$ & $p-\mathrm{Cl}$ & 2.79 & 1.43 & 2.08 \\
$p-\mathrm{OMe}$ & $\mathrm{H}$ & $\mathrm{H}$ & 5.29 & 2.42 & 2.19 \\
$p-\mathrm{OMe}$ & $\mathrm{H}$ & $p-\mathrm{NO}_{2}$ & 36.0 & 16.8 & 2.14 \\
$\mathrm{H}$ & $\mathrm{H}$ & $p-\mathrm{OMe}$ & 1.12 & 0.528 & 2.12 \\
$p-\mathrm{OMe}$ & $\mathrm{Br}$ & $p-\mathrm{OMe}$ & 4.19 & 2.11 & 1.99 \\
$p-\mathrm{Cl}$ & $\mathrm{Br}$ & $\mathrm{H}$ & 3.74 & 1.85 & 2.02 \\
\hline
\end{tabular}

acceptor $\mathrm{Y}\left(\delta \sigma_{\mathrm{Y}}>0\right)$ or $\mathrm{Y}^{\prime}\left(\delta \sigma_{\mathrm{Y}^{\prime}}>0\right)$ will result in greater charge development, $\delta \sigma_{\mathrm{Y}}>0$ or $\delta \sigma_{\mathrm{Y}^{\prime}}>0$, since $\rho_{\mathrm{YY}^{\prime}}=\delta \rho_{\mathrm{Y}^{\prime}}$ / $\delta \sigma_{\mathrm{Y}}=\delta \rho_{\mathrm{Y}} / \delta \sigma_{\mathrm{Y}^{\prime}}>0$. This is supported by the greater magnitude of $\rho_{\mathrm{X}}$ (and $\beta_{\mathrm{X}}$ ) for stronger acceptor $\mathrm{Y}$ and $\mathrm{Y}^{\prime}$ as can be seen in Table 2; the greater the magnitude of $\rho_{\mathrm{X}}$ (and $\beta_{\mathrm{X}}$ ), the greater is the degree of bond formation and hence the greater becomes the pi-bond cleavage in the TS with a stronger anionic charge development on $\mathrm{C}_{\alpha}$ as well as on $\mathrm{C}_{\beta}$ in the TS.

The kinetic isotope effects involving deuterated benzylamine nucleophiles ${ }^{2,9}\left(\mathrm{XC}_{6} \mathrm{H}_{4} \mathrm{CH}_{2} \mathrm{ND}_{2}\right)$ are quite large with a $k_{\mathrm{H}} / k_{\mathrm{D}}=1.99-2.40$ (Table 4 ) indicating that strong hydrogen bonding of the N-H(D) proton toward the anionic center, $\mathrm{C}_{\alpha}$, in the TS. Thus the reaction proceeds in a single step with concurrent formation $\mathrm{N}-\mathrm{C}_{\beta}$ and $\mathrm{H}-\mathrm{C}_{\alpha}$ bond, 3 .

The relatively low activation enthalpies, $\Delta \mathrm{H}^{\neq}$, and large

Table 5. Activation parameters for the reactions of $\alpha$-phenyl- $\beta$ thiophenylacrylonitriles with X-benzylamines in acetonitrile ${ }^{a}$

\begin{tabular}{|c|c|c|c|c|c|c|}
\hline$X$ & Y & $Y^{\prime}$ & $\begin{array}{c}\mathrm{T} \\
\left({ }^{\circ} \mathrm{C}\right)\end{array}$ & $\begin{array}{c}k\left(10^{4}\right. \\
\left.\mathrm{M}^{-1} \mathrm{~s}^{-1}\right)\end{array}$ & $\begin{array}{c}\Delta \mathrm{H}^{\neq} \\
\left(\mathrm{kcalmol}^{-1}\right)\end{array}$ & $\begin{array}{c}-\Delta \mathrm{S}^{\neq} \\
\left(\mathrm{calmol}^{-1} \mathrm{~K}^{-1}\right)\end{array}$ \\
\hline \multirow[t]{3}{*}{$p$-OMe } & $\mathrm{Me}$ & $\mathrm{H}$ & 25 & 2.02 & 9.2 & 45 \\
\hline & & & 30 & 2.73 & & \\
\hline & & & 35 & 3.45 & & \\
\hline \multirow[t]{3}{*}{$p$-OMe } & $\mathrm{H}$ & $p$-Me & 25 & 2.67 & 8.6 & 46 \\
\hline & & & 30 & 3.42 & & \\
\hline & & & 35 & 4.38 & & \\
\hline \multirow[t]{3}{*}{$p$-OMe } & $\mathrm{Br}$ & $\mathrm{H}$ & 25 & 11.8 & 9.3 & 41 \\
\hline & & & 30 & 15.5 & & \\
\hline & & & 35 & 20.3 & & \\
\hline \multirow[t]{3}{*}{$p-\mathrm{NO}_{2}$} & $\mathrm{Me}$ & $\mathrm{H}$ & 25 & 0.483 & 11 & 43 \\
\hline & & & 30 & 0.653 & & \\
\hline & & & 35 & 0.892 & & \\
\hline \multirow[t]{3}{*}{$p-\mathrm{NO}_{2}$} & $\mathrm{H}$ & $\mathrm{H}$ & 25 & 0.704 & 9.8 & 45 \\
\hline & & & 30 & 0.931 & & \\
\hline & & & 35 & 1.25 & & \\
\hline \multirow[t]{3}{*}{$p-\mathrm{NO}_{2}$} & $\mathrm{Br}$ & $p$-Me & 25 & 0.784 & 11 & 42 \\
\hline & & & 30 & 1.07 & & \\
\hline & & & 35 & 1.45 & & \\
\hline
\end{tabular}

$\overline{{ }^{a} \text { Calculated by using Erying equation. The maximum errors calculated }}$ (by the method of K. B. Wiberg, Physical Organic Chemistry; Wily, New York, $1964, p 378)$ are \pm 0.5 e.u. and \pm 2 e.u. for $\Delta H^{\ddagger}$ and $\Delta \mathbf{S}^{\neq}$, respectively. 
negative entropies of activation, $\Delta S^{\neq}$, in Table 5 , are consistent with a four-centered constrained TS structure, $\mathbf{3}$, proposed. $^{2}$

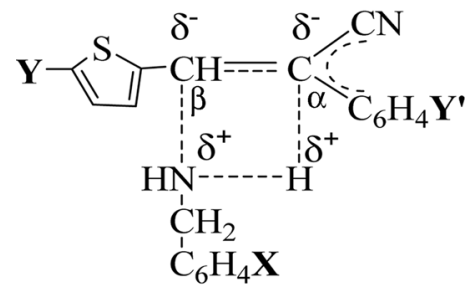

3

\section{Experimental Section}

General procedure. GR grade acetonitrile was purchased from Merck and used without distillation. The benzylamine nucleophiles, Merck GR grade were used without re crystallization. Melting points were measured using a Tomas Hoover 6427-H10. Infrared spectra were taken using a Shimadzu FT-IR spectrophotometer. ${ }^{1} \mathrm{H}$ NMR spectra were recorded on Bruker Advance $300 \mathrm{MHz}$ instrument using $\mathrm{CDCl}_{3}$ as solvent, unless otherwise stated, with TMS as an internal standard. UV-Vis spectra were obtained on a Shimadzu UV-2401PC spectrophotometer. Kinetic experiments were performed using a Shimadzu UV-2401PC spectrophotometer.

Preparations of $\alpha$-phenyl- $\beta$-thiophenylacrylonitriles. The $p$-substituted acrylonitriles $\left(20 \mathrm{mmol} ; 4-\mathrm{OCH}_{3}, 4-\mathrm{CH}_{3}\right.$, $4-\mathrm{H}, 4-\mathrm{Cl}, 4-\mathrm{NO}_{2}$ ) was prepared by condensation of 2substitued thiophene aldehyde (2-Me, 2-H, 2-Br) with a appropriate arylacetonitrile in the presence of base; a solution of the aldehyde $(20 \mathrm{mmol})$ and arylacetonitrile $(20$ $\mathrm{mmol})$ were shaken in warm ethanol with a few drops of $30 \%$ aqueous potassium hydroxide. The mixture was stirred at room temperature. The reaction controlled by TLC showed quickly disappearance of the starting regents. The substance precipitated was washed with water and recrystallized from $\mathrm{EtOH}$.

4- $\mathbf{C H}_{3} \mathbf{C}_{4} \mathbf{S H}_{2} \mathbf{C H}=\mathbf{C}(\mathbf{C N}) \mathbf{C}_{6} \mathbf{H}_{4} \mathbf{O C H}_{3}-p$. IR $(\mathrm{KBr}): 2210$ $(\mathrm{CN}), 1591(\mathrm{C}=\mathrm{C}),{ }^{1} \mathrm{H}$ NMR $\left(300 \mathrm{MHz}, \mathrm{CDCl}_{3}\right)(\delta) 2.55(\mathrm{~s}$, $\left.3 \mathrm{H}, \mathrm{CH}_{3}\right), 3.84\left(\mathrm{~s}, 3 \mathrm{H}, \mathrm{OCH}_{3}\right), 6.78$ (m, $1 \mathrm{H}$ (thiophene)), $6.93(\mathrm{~d}, J=9.0 \mathrm{~Hz}, 2 \mathrm{H}$ (aromatic)), 7.36 (d, $J=3.6 \mathrm{~Hz}, 1 \mathrm{H}$ (thiophene)), 7.45 (s, 1H (alkene)), 7.55 (d, $J=9.0 \mathrm{~Hz}, 2 \mathrm{H}$ (aromatic)).

4- $\mathbf{C H}_{3} \mathbf{C}_{\mathbf{4}} \mathbf{S H}_{2} \mathbf{C H}=\mathbf{C}(\mathbf{C N}) \mathbf{C}_{6} \mathbf{H}_{4} \mathbf{C H}_{3}-\boldsymbol{p}$. IR $(\mathrm{KBr}): 2208$ $(\mathrm{CN}), 1590(\mathrm{C}=\mathrm{C}),{ }^{1} \mathrm{H}$ NMR $\left(300 \mathrm{MHz}, \mathrm{CDCl}_{3}\right)(\delta) 2.37$ (s, $3 \mathrm{H}, \mathrm{CH}_{3}$ (thiophene)), 2.55 (s, 3H, $\mathrm{CH}_{3}$ (aromatic)), 6.79 (m, $1 \mathrm{H}$ (thiophene)), 7.21 (d, $J=7.8 \mathrm{~Hz}, 2 \mathrm{H}$ (aromatic)), 7.38 (d, $J=3.6 \mathrm{~Hz}, 1 \mathrm{H}$ (thiophene)), 7.49-7.53 (m, 3H ((2H, aromatic), (1H, alkene))).

4- $\mathbf{C H}_{3} \mathbf{C}_{4} \mathbf{S H}_{2} \mathbf{C H}=\mathbf{C}(\mathbf{C N}) \mathbf{C}_{6} \mathbf{H}_{5}$. IR $(\mathrm{KBr}): 2209(\mathrm{CN})$, $1592(\mathrm{C}=\mathrm{C}),{ }^{1} \mathrm{H}$ NMR $\left(300 \mathrm{MHz}, 4-\mathrm{CDCl}_{3}\right)(\delta) 2.56(\mathrm{~s}, 3 \mathrm{H}$, $\mathrm{CH}_{3}$ (thiophene)), 6.8 (m, 1H (thiophene)), 7.31-7.44 (m, 4H $((3 \mathrm{H}$, aromatic), $(1 \mathrm{H}$, thiophene $))), 7.57$ (s, 1H (alkene)), 7.60-7.63 (m, 2H (benzene)).

4- $\mathrm{CH}_{3} \mathrm{C}_{4} \mathbf{S H}_{2} \mathbf{C H}=\mathbf{C}(\mathrm{CN}) \mathrm{C}_{6} \mathrm{H}_{4} \mathrm{Cl}-p . \quad$ IR $\quad(\mathrm{KBr}): 2210$
$(\mathrm{CN}), 1589(\mathrm{C}=\mathrm{C}),{ }^{1} \mathrm{H}$ NMR $\left(300 \mathrm{MHz}, \mathrm{CDCl}_{3}\right)(\delta) 2.56(\mathrm{~s}$, $3 \mathrm{H}, \mathrm{CH}_{3}$ (thiophene)), $6.80(\mathrm{~m}, 1 \mathrm{H}$ (thiophene)), $7.38(\mathrm{~d}, J=$ $8.7 \mathrm{~Hz}, 2 \mathrm{H}$ (aromatic)), 7.41 ( $\mathrm{s}, J=3.9 \mathrm{~Hz}, 1 \mathrm{H}$ (thiophene)), 7.54 (s, 1H (alkene)), 7.55 (d, $J=8.7 \mathrm{~Hz}, 2 \mathrm{H}$ (aromatic)).

4- $\mathrm{CH}_{3} \mathbf{C}_{4} \mathbf{S H}_{2} \mathbf{C H}=\mathbf{C}(\mathbf{C N}) \mathbf{C}_{6} \mathbf{H}_{4} \mathbf{N O}_{2}-p$. IR $(\mathrm{KBr}): 2211$ (CN), $1590(\mathrm{C}=\mathrm{C}),{ }^{1} \mathrm{H}$ NMR $\left(300 \mathrm{MHz}, \mathrm{CDCl}_{3}(\delta) 2.60(\mathrm{~s}\right.$, $3 \mathrm{H}, \mathrm{CH}_{3}$ (thiophene)), 6.88 (m, 1H (thiophene)), 7.52 (d, $J=$ $3.9 \mathrm{~Hz}, 1 \mathrm{H}$ (thiophene)), 7.73 (s, 1H (alkene)), 7.78 (d, $J=$ $9.0 \mathrm{~Hz}, 2 \mathrm{H}$ (aromatic)), 8.28 (d, $J=9.0 \mathrm{~Hz}, 2 \mathrm{H}$ (aromatic)).

$\mathbf{C}_{4} \mathbf{H}_{3} \mathbf{S C H}=\mathbf{C}(\mathbf{C N}) \mathbf{C}_{6} \mathbf{H}_{4} \mathbf{O C H}_{3}-p$. IR (KBr): $2208(\mathrm{CN})$, $1590(\mathrm{C}=\mathrm{C}),{ }^{1} \mathrm{H}$ NMR (300 MHz, $\left.\mathrm{CDCl}_{3}\right)(\delta) 3.87(\mathrm{~s}, 3 \mathrm{H}$, $\mathrm{OCH}_{3}$ (aromatic)), $6.97(\mathrm{~d}, J=9.0 \mathrm{~Hz}, 2 \mathrm{H}$ (aromatic)) 7.15 (m, 1H (thiophene)), 7.52 (d, $J=5.1 \mathrm{~Hz}, 1 \mathrm{H}$ (thiophene)), 7.56 (s, 1H (alkene)), 7.59 (d, $J=9.0 \mathrm{~Hz}, 2 \mathrm{H}$ (aromatic), $7.64(\mathrm{~d}, J=3.6 \mathrm{~Hz}, 2 \mathrm{H}$ (thiophene)).

$\mathbf{C}_{4} \mathbf{H}_{3} \mathbf{S C H}=\mathbf{C}(\mathbf{C N}) \mathbf{C}_{6} \mathbf{H}_{4} \mathbf{C H}_{3}-\boldsymbol{p}$. IR (KBr): $2207(\mathrm{CN}), 1594$ $(\mathrm{C}=\mathrm{C}),{ }^{1} \mathrm{H}$ NMR $\left(300 \mathrm{MHz}, \mathrm{CDCl}_{3}\right)(\delta) 2.39$ (s, 3H, $\mathrm{CH}_{3}$ (aromatic)), 7.14 (m, 1H (thiophene)), 7.24 (d, $J=8.1 \mathrm{~Hz}$, $2 \mathrm{H}$ (aromatic)), 7.52-7.55 (m, 3H (2H (aromatic), $1 \mathrm{H}$ (thiophene))), 7.62 (s, 1H (alkene)), 7.64 (d, $J=3.9 \mathrm{~Hz}, 1 \mathrm{H}$ (thiophene)).

$\mathbf{C}_{\mathbf{4}} \mathbf{H}_{3} \mathbf{S C H}=\mathbf{C}(\mathbf{C N}) \mathbf{C}_{6} \mathbf{H}_{5}-p$. IR $(\mathrm{KBr}): 2206(\mathrm{CN}), 1591$ $(\mathrm{C}=\mathrm{C}),{ }^{1} \mathrm{H}$ NMR $\left(300 \mathrm{MHz}, \mathrm{CDCl}_{3}\right)(\delta) 7.14(\mathrm{~m}, 1 \mathrm{H}$ (thiophene)), 7.33-7.45 (m, 3H (aromatic)), 7.53 (d, $J=5.1$ $\mathrm{Hz}, 1 \mathrm{H}$ (thiophene)), 7.62-7.66 (m, 4H (1H (alkene), 2H (aromatic), 1H (thiophene))).

$\mathbf{C}_{4} \mathbf{H}_{3} \mathbf{S C H}=\mathbf{C}(\mathbf{C N}) \mathbf{C}_{6} \mathbf{H}_{4} \mathrm{Cl}-p$. IR $(\mathrm{KBr}): 2210(\mathrm{CN}), 1600$ $(\mathrm{C}=\mathrm{C}),{ }^{1} \mathrm{H}$ NMR $\left(300 \mathrm{MHz}, \mathrm{CDCl}_{3}\right)(\delta) 7.15(\mathrm{~m}, 1 \mathrm{H}$ (thiophene)), $7.40(\mathrm{~d}, J=8.7 \mathrm{~Hz}, 2 \mathrm{H}$ (aromatic)) 7.55-7.58 (m, 3H (2H (aromatic), 1H (thiophene))), 7.63 (s, 1H (alkene)), $7.66(\mathrm{~d}, J=3.6 \mathrm{~Hz}, 1 \mathrm{H}$ (thiophene)).

$\mathbf{C}_{4} \mathbf{H}_{3} \mathbf{S C H}=\mathbf{C}(\mathbf{C N}) \mathbf{C}_{6} \mathbf{H}_{4} \mathbf{N O}_{2}-p$. IR $(\mathrm{KBr}): 2212(\mathrm{CN})$, $11593(\mathrm{C}=\mathrm{C}),{ }^{1} \mathrm{H}$ NMR $\left(300 \mathrm{MHz}, \mathrm{CDCl}_{3}\right)(\delta) 7.21(\mathrm{~m}, 1 \mathrm{H}$ (thiophene)), 7.67 (d, $J=5.1 \mathrm{~Hz}, 1 \mathrm{H}$ (thiophene)), 7.72 (d, $J$ $=3.9 \mathrm{~Hz}, 1 \mathrm{H}$ (thiophene)), 7.80-7.83 (m, 3H (2H (aromatic), $1 \mathrm{H}$ (alkene)), $8.29(\mathrm{~d}, J=8.7 \mathrm{~Hz}, 2 \mathrm{H}$ (aromatic)).

4- $\mathrm{BrC}_{4} \mathbf{S H}_{2} \mathbf{C H}=\mathbf{C}(\mathbf{C N}) \mathbf{C}_{6} \mathbf{H}_{4} \mathbf{O C H}_{3}-p$. IR $(\mathrm{KBr}): 2200$ $(\mathrm{CN}), 1596(\mathrm{C}=\mathrm{C}),{ }^{1} \mathrm{H} \mathrm{NMR}\left(300 \mathrm{MHz}, \mathrm{CDCl}_{3}\right)(\delta) 3.84(\mathrm{~s}$, $3 \mathrm{H}, \mathrm{OCH}_{3}$ (aromatic)), $6.94(\mathrm{~d}, J=9.0 \mathrm{~Hz}, 2 \mathrm{H}$ (aromatic)), 7.08 (d, $J=3.9 \mathrm{~Hz}, 1 \mathrm{H}$ (thiophene)), 7.28 (d, $J=3.9 \mathrm{~Hz}, 2 \mathrm{H}$ (thiophene)), 7.40 (s, 1H (alkene)), $7.55(\mathrm{~d}, J=8.7 \mathrm{~Hz}, 2 \mathrm{H}$ (aromatic)).

4-BrC $\mathbf{S H}_{2} \mathbf{C H}=\mathbf{C}(\mathbf{C N}) \mathbf{C}_{6} \mathbf{H}_{4} \mathbf{C H}_{3}-p . \quad$ IR $\quad(\mathrm{KBr}): 2209$ $(\mathrm{C}=\mathrm{C}), 1591(\mathrm{C}=\mathrm{C}),{ }^{1} \mathrm{H}$ NMR (300 MHz, $\left.\mathrm{CDCl}_{3}\right)(\delta) 2.38$ (s, 3H, $\mathrm{CH}_{3}$ (aromatic)), $7.09(\mathrm{~d}, J=4.2 \mathrm{~Hz}, 1 \mathrm{H}$ (thiophene)), $7.23(\mathrm{~d}, J=8.4 \mathrm{~Hz}, 2 \mathrm{H}$ (aromatic)), $7.31(\mathrm{~d}, J=$ $3.9 \mathrm{~Hz}, 1 \mathrm{H}$ (aromatic)), 7.48 (s, 1H (alkene)), 7.51 (d, $J=8.1$ $\mathrm{Hz}, 2 \mathrm{H}$ (aromatic)).

4-BrCS $\mathbf{S}_{\mathbf{4}} \mathbf{H}_{\mathbf{2}} \mathbf{C H}=\mathbf{C}(\mathbf{C N}) \mathbf{C}_{\mathbf{6}} \mathbf{H}_{5}$. IR (KBr): $2210(\mathrm{CN}), 1594$ $(\mathrm{C}=\mathrm{C}),{ }^{1} \mathrm{H}$ NMR $\left(300 \mathrm{MHz}, \mathrm{CDCl}_{3}\right)(\delta) 7.10(\mathrm{~d}, J=4.2 \mathrm{~Hz}$, $1 \mathrm{H}$ (thiophene)), 7.33 (d, $J=3.9 \mathrm{~Hz}, 1 \mathrm{H}$ (thiophene)), 7.377.46 (m, 3H (aromatic)), 7.53 (s, 1H (alkene)), 7.60-7.64 (m, $2 \mathrm{H}$ (aromatic)).

4- $\mathrm{BrC}_{4} \mathbf{S H}_{2} \mathbf{C H}=\mathbf{C}(\mathbf{C N}) \mathbf{C}_{6} \mathbf{H}_{4} \mathbf{C l}-p . \quad \mathrm{R}(\mathrm{KBr}): 2212(\mathrm{CN})$, $1600(\mathrm{C}=\mathrm{C}),{ }^{1} \mathrm{H}$ NMR $\left(300 \mathrm{MHz}, \mathrm{CDCl}_{3}\right)(\delta) 7.11(\mathrm{~d}, J=3.9$ $\mathrm{Hz}, 1 \mathrm{H}$ (thiophene)), 7.33 (d, $J=4.2 \mathrm{~Hz}, 1 \mathrm{H}$ (thiophene)), 7.40 (d, $J=8.7 \mathrm{~Hz}, 2 \mathrm{H}$ (aromatic)), 7.50 (s, 1H (alkene)), 


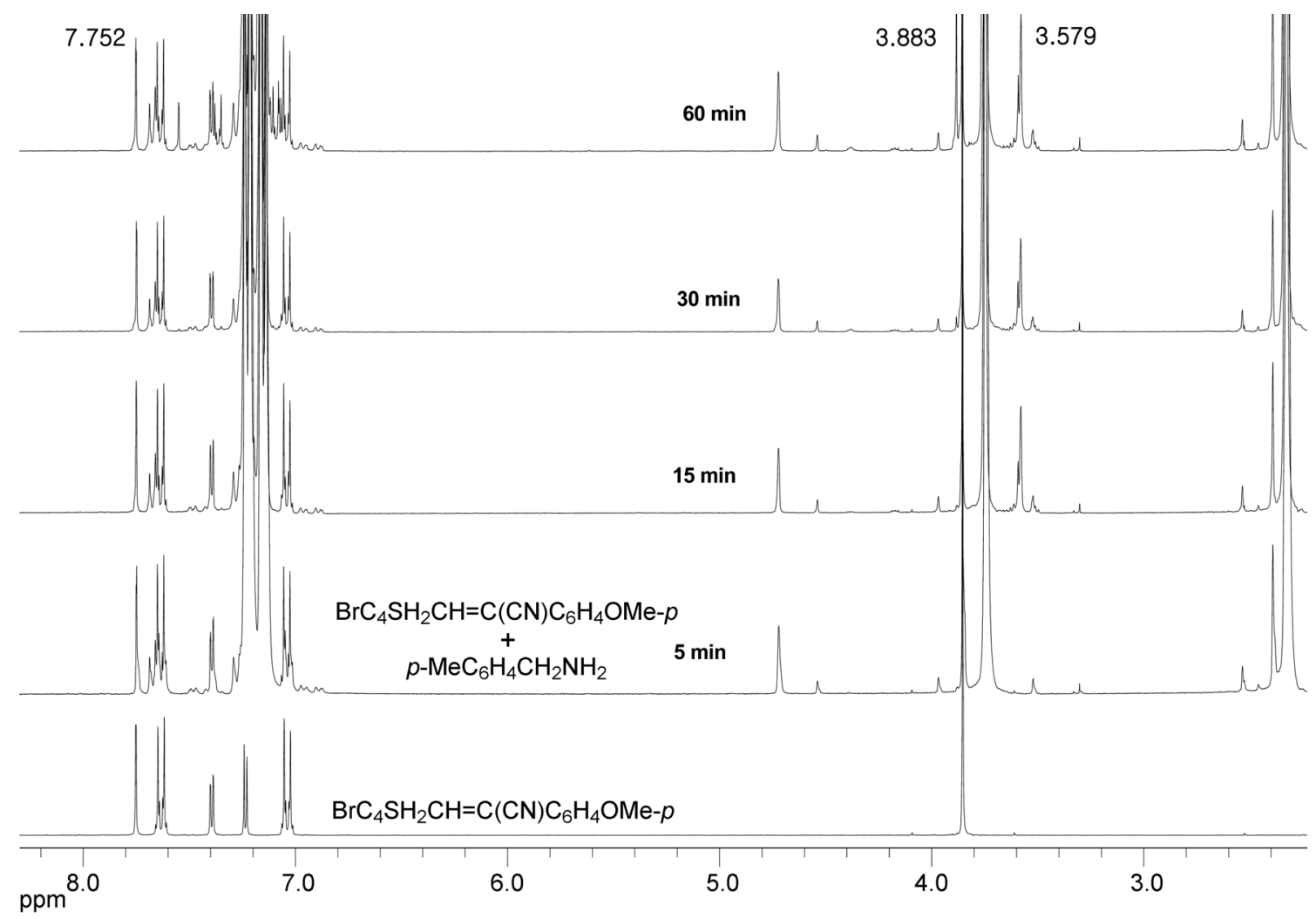

Figure 5. ${ }^{1} \mathrm{H}-\mathrm{NMR}$ spectra for the reaction $\mathrm{BrC}_{4} \mathrm{SH}_{2} \mathrm{CH}=\mathrm{C}(\mathrm{CN}) \mathrm{C}_{6} \mathrm{H}_{4} \mathrm{OMe}-p$ with $p-\mathrm{MeC}_{6} \mathrm{H}_{4} \mathrm{CH}_{2} \mathrm{NH}_{2}$ in $\mathrm{CD}_{3} \mathrm{CN}$ at $25.0{ }^{\circ} \mathrm{C}$.

$7.55(\mathrm{~d}, J=8.7 \mathrm{~Hz}, 2 \mathrm{H}$ (aromatic)).

4-BrC $\mathbf{C H}_{\mathbf{2}} \mathbf{C H}=\mathbf{C}(\mathbf{C N}) \mathbf{C}_{6} \mathbf{H}_{4} \mathbf{N O}_{2}-p . \quad$ IR $\quad(\mathrm{KBr}): 2207$ $(\mathrm{CN}), 1592(\mathrm{C}=\mathrm{C}),{ }^{1} \mathrm{H} \mathrm{NMR}\left(300 \mathrm{MHz}, \mathrm{CDCl}_{3}\right)(\delta) 7.18(\mathrm{~m}$, $1 \mathrm{H}$ (thiophene)), 7.49 (d, $J=4.2 \mathrm{~Hz}, 1 \mathrm{H}$ (thiophene)), 7.63 (d, 2H, $J=9.0 \mathrm{~Hz}$ (aromatic)), 7.63 (s, 1H (alkene)), 7.80 (d, $2 \mathrm{H}, J=9.0 \mathrm{~Hz}$ (aromatic)).

Kinetic Measurement. The reactions was followed spectrophotometrically by monitoring the decrease in the concentration of $\alpha$-phenyl- $\beta$-thiophenylacylonitriles, [PTA], at $\lambda_{\max }$ of the substrate to over $80 \%$ completion. The reaction was studied under pseudo-first-order condition, [PTA] $=5.5$ $\times 10^{-5} \mathrm{M}$ and $[\mathrm{BA}]=(2.5-5.2) \times 10^{-1} \mathrm{M}$ at $25.0^{\circ} \mathrm{C}$. The pseudo first-order rate constant, $k_{\mathrm{obs}}$, was determined from the slope of the plot $(r>0.996)$ of $\ln [\mathrm{PTA}]$ vs time. Secondorder rate constants, $k_{2}$, were obtained from the slope of a plot $(r>0.996)$ of $k_{\text {obs }} v s$ [BA] with more than four concentrations of benzylamine, carried out more than two runs, and were reproducible to within $\pm 3 \%$.

Product Analysis. The analysis of final product was difficult due to partial decomposition during product separation and purification. We therefore analyzed the reaction mixture by NMR (Bruker $300 \mathrm{MHz}$ ) at appropriate intervals under exactly the same reaction conditions as the kinetic measurement in $\mathrm{CD}_{3} \mathrm{CN}$ at $25.0{ }^{\circ} \mathrm{C}$ using larger amount of reactants. Initially we found a peaks for olefin $\mathrm{CH}$ in the products, $4-\mathrm{BrC}_{4} \mathrm{SH}_{2} \mathrm{CH}=\mathrm{C}(\mathrm{CN}) \mathrm{C}_{6} \mathrm{H}_{4} \mathrm{OMe}-p$, at 7.752 ppm, which was gradually reduced, and two new peaks for $\mathrm{CH}-\mathrm{CH}$ in the product, $4-\mathrm{BrC}_{4} \mathrm{SH}_{2}\left(p-\mathrm{MeC}_{6} \mathrm{H}_{4} \mathrm{CH}_{2} \mathrm{NH}\right)-$ $\mathrm{CHCH}(\mathrm{CN}) \mathrm{C}_{6} \mathrm{H}_{4} \mathrm{OMe}-p$, grew at 3.883 and 3.579 ppm as the reaction proceeded. No other peaks or complications were found during the reaction except the three-peak height changes, indicating that the reaction proceeds with no other side reactions (Figure 5).

\section{References}

1. (a) Bernasconi, C. F. Acc. Chem. Res. 1987, 20, 301. (b) Bernasconi, C. F. Tetrahedron 1989, 45, 4017.

2. (a) Oh, H. K.; Yang, J. H.; Sung, D. D.; Lee, I. J. Chem. Soc., Perkin Trans. 2 2000, 101. (b) Oh, H. K.; Yang, J. H.; Lee, H. W. Lee, I. J. Org. Chem. 2000, 65, 2188. (c) Oh, H. K.; Yang, J. H.; Lee, H. W.; Lee, I. J. Org. Chem. 2000, 65, 5391. (d) Oh, H. K.; Kim, I. K.; Sung, D. D.; Lee, I. Org. Biomol. Chem. 2004, 2, 1213. (e)Oh, H. K.; Kim, I. K.; Sung, D. D.; Lee, I. Bull. Korean Chem. Soc. 2005, 26, 641 .

3. Lee, I. Adv. Phys. Org. Chem. 1992, 27, 57.

4. (a) Lee, I.; Lee, H. W. Collect. Czech. Chem. Commun. 1999, 64, 1529. (b) Lee, I. Chem. Soc. Rev. 1990, 19, 317. (c) Oh, H. K.; Kim, T. S.; Lee, H. W.; Lee, I. Bull. Korean Chem. Soc. 2003, 24, 193.

5. (a) Imoto, E.; Motoyama, R. Bull. Naniwa Univ. $2 A$ 1954, 127. (b) Imoto, E.; Motoyama, R. Chem. Abs. 1955, 49, 9614. (c) Charton, M. Correlation Analysis in Chemistry; Plenum Press: New York and London, 1978; pp 199-200.

6. (a) Ritchie, C. D. In Solute-Solvent Interactions; Coetzee, J. F., Ritchie, C. D., Eds.; Marcel Dekker: New York, 1969; Chapter 4. (b) Coetzee, J. F. Progress in Physical Organic Chemistry; Streitwieser, A., Jr., Taft, R. W., Eds.; Wiley; New York, 1967; Vol. 4, pp 54-92. (c) Spillane, W. J.; Hogan, G.; McGrath, P.; King, J.; Brack, C. J. Chem. Soc., Perkin Trans. 2 1996, 2099. (d) Lee, I.; Kim, C. K.; Han, I. S.; Lee, H. W.; Kim, W. K.; Kim, Y. B. J. Phys. Chem. B 1999, 103, 7302.

7. Lee, I.; Rhee, S. K.; Kim, C. K.; Chung, D. S.; Kim, C. K. Bull. Korean Chem. Soc. 2000, 21, 882.

8. Lee, I. Chem. Soc. Rev. 1990, 19, 317.

9. Lee, I. Chem. Soc. Rev. 1995, 24, 223. 